\title{
Hydrogen peroxide and sodium hypochlorite disinfectants are more effective against Staphylococcus aureus and Pseudomonas aeruginosa biofilms than quaternary ammonium compounds
}

\author{
Caitlinn B. Lineback', Carine A. Nkemngong ${ }^{1}$, Sophie Tongyu Wu' ${ }^{1}$, Xiaobao Li², Peter J. Teska ${ }^{2}$ and Haley F. Oliver ${ }^{1 *}$ (D)
}

\begin{abstract}
Background: Antimicrobial disinfectants are used as primary treatment options against pathogens on surfaces in healthcare facilities to help prevent healthcare associated infections (HAls). On many surfaces, pathogenic microorganisms exist as biofilms and form an extracellular matrix that protects them from the antimicrobial effects of disinfectants. Disinfectants are used as all-purpose antimicrobials though very few specifically make biofilm efficacy claims. The objective of this study was to evaluate the efficacy of eight registered disinfectants (six registered by the Environmental Protection Agency and two products registered in by the European Chemical Agency) with general bactericidal claims, but currently no biofilm efficacy claims, against Staphylococcus aureus ATTC-6538 and Pseudomonas aeruginosa ATCC-15442 biofilms. We hypothesized that hydrogen peroxide and sodium hypochlorite disinfectant products would be more effective than quaternary ammonium chlorides.

Methods: This study tested the bactericidal efficacy of eight registered disinfectant products against $S$. aureus ATCC-6538 and P. aeruginosa ATCC-15442 grown on glass coupons using a Center for Disease Control (CDC) biofilm reactor and EPA MLB SOP MB-19. Bactericidal efficacy was determined after treating coupons with disinfectants following standard EPA MLB SOP MB-20.

Results: Overall, sodium hypochlorite and hydrogen peroxide disinfectants had significantly higher bactericidal efficacies than quaternary ammonium chloride disinfectants. We also found that all tested disinfectants except for quaternary ammonium chloride disinfectants met and exceeded the EPA standard for bactericidal efficacy against biofilms.

Conclusion: In general, bactericidal efficacy against biofilms differed by active ingredient. The efficacies of sodium hypochlorite and hydrogen peroxide disinfectants did not vary between strains, but there were significant differences between strains treated with quaternary ammonium chloride disinfectants.
\end{abstract}

Keywords: Disinfectant, Biofilms, Efficacy

\footnotetext{
*Correspondence: hfoliver@purdue.edu

${ }^{1}$ Department of Food Science, Purdue University, 745 Agriculture Mall Drive,

West Lafayette, IN 47907, USA

Full list of author information is available at the end of the article
}

(c) The Author(s). 2018 Open Access This article is distributed under the terms of the Creative Commons Attribution 4.0 International License (http://creativecommons.org/licenses/by/4.0/), which permits unrestricted use, distribution, and reproduction in any medium, provided you give appropriate credit to the original author(s) and the source, provide a link to the Creative Commons license, and indicate if changes were made. The Creative Commons Public Domain Dedication waiver (http://creativecommons.org/publicdomain/zero/1.0/) applies to the data made available in this article, unless otherwise stated. 


\section{Background}

Healthcare associated infections (HAIs) are reported to occur in one out of 25 patients daily on average in the US [1] with over 2 million patients contracting HAIs annually [2]. In the USA, the overall incidence of HAIs is estimated to have increased by $36 \%$ in the last two decades [3]. Bacterial biofilms account for 65 and $80 \%$ of microbial and chronic infections, respectively [4]. A 2012 study suggested that biofilms may serve as a source of infections by periodically releasing planktonic bacterial cells into the environment [5]. The use of disinfectants is critical to preventing transmission of infectious pathogens from contaminated surfaces and medical equipment to patients $[6,7]$. Despite emphasis on surface disinfection, pathogenic microorganisms are routinely isolated from the hospital environment $[5,7]$.

Within healthcare facilities, Staphylococcus aureus and Pseudomonas aeruginosa are amongst the most problematic pathogens [8] with S. aureus being the second most common pathogen that caused HAIs [9]. These pathogens grow on hard non-porous surfaces such as metal pipes and floor drains [10] and develop an extracellular polymeric matrix that protects the cells from adverse conditions $[4,11]$. It has also been shown that the biofilm matrix enhances tolerance to disinfectants by encasing the underlying cells $[12,13]$ and by limiting diffusion of disinfectants into the biofilm matrix [14]. In fact, the bactericidal efficacy of disinfectants on biofilms is much lower compared to the efficacy of the same disinfectants against planktonic cells [8, 15-17]. The tolerance of biofilms to disinfectants is dependent on disinfectant active, temperature, and the type of surface [13]. Surface roughness, surface humidity, and the availability of nutrients influence the establishment of biofilms on surfaces [18]. Moist surfaces have been shown to be more favorable for biofilm growth even though biofilms have also been reported to grow on dry surfaces $[4,14]$.

Disinfectants are primary intervention options against pathogenic organisms on surfaces in healthcare facilities $[7,14]$ and are used as broad-spectrum antimicrobials [19]. Common antimicrobials used for disinfecting surfaces in healthcare facilities include quaternary ammonium compounds, hydrogen peroxide, and chlorine-based products $[6,17]$. There are few published studies that investigate the efficacy of disinfectants on bacterial biofilms at label use concentrations. The objective of this study was to evaluate the efficacy of eight registered disinfectants with general bactericidal claims, but no current biofilm efficacy claims, against $S$. aureus ATTC-6538 and P. aeruginosa ATCC-15442 biofilms. We hypothesized that accelerated hydrogen peroxide disinfectant products would be more effective than quaternary ammonium compounds and that sodium hypochlorite disinfectants would be the most effective at eliminating biofilms.

\section{Methods}

Disinfectants and bacteria strains used in this study

This study tested the bactericidal efficacy of eight registered disinfectant products (Table 1) against $S$. aureus ATCC-6538 and P.s aeruginosa ATCC-15442. These

Table 1 Active ingredients and contact times for disinfectant products tested in this study

\begin{tabular}{|c|c|c|c|c|}
\hline $\begin{array}{l}\text { Disinfectant Product "Name" } \\
\text { (used in the manuscript or figures) }^{a}\end{array}$ & $\begin{array}{l}\text { Disinfectant Active } \\
\text { Ingredient }(s)^{c}\end{array}$ & Dilution & Active Level at Use & $\begin{array}{l}\text { Label Contact Time } \\
\text { (mins) }^{f}\end{array}$ \\
\hline HP1 & $0.5 \%$ hydrogen peroxide & $R T U^{d}$ & $0.5 \%$ & 1 \\
\hline HP2 & 0.5\% Hydrogen Peroxide & RTU & $0.5 \%$ & 1 \\
\hline $\mathrm{HP} 3^{b}$ & $7.0 \%$ hydrogen peroxide & RTU & $7.0 \%$ & 1 \\
\hline $\mathrm{HP} 4^{\mathrm{b}}$ & 7.2\% hydrogen peroxide & $1: 20$ & $0.36 \%$ & 5 \\
\hline HP5 & $4.25 \%$ hydrogen peroxide & $1: 16$ & $0.27 \%$ & 5 \\
\hline Q1 & $\begin{array}{l}\text { 6.67\% octyl decyl ammonium chloride; } 2.67 \% \\
\text { docctyl dimethyl ammonium chloride; } 4.00 \% \\
\text { didecyl dimethyl ammonium chloride; } 8.90 \% \text { alkyl } \\
\left(C_{14}, 50 \% ; C_{12}, 40 \% ; C_{16}, 10 \%\right) \text { dimethyl } \\
\text { benzyl ammonium chloride }\end{array}$ & $1: 256$ & $0.087 \%$ & 3 \\
\hline Q2 & $\begin{array}{l}\text { 8.704\% didecyl dimethyl ammonium chloride; } \\
8.190 \% \text { n-alkyl }\left(C_{14}, 50 \% ; C_{12}, 40 \% ; C_{16}, 10 \%\right) \\
\text { dimethyl benzyl ammonium chloride }\end{array}$ & $1: 256$ & $0.066 \%$ & 10 \\
\hline SH1 & $1.312 \%$ sodium hypochlorite & RTU & $1.312 \%$ & 4 \\
\hline
\end{tabular}

${ }^{a}$ Naming scheme abbreviates the active ingredients of the products used in this study and differentiates products with the same class of active ingredients by numbers

${ }^{\mathrm{b}} \mathrm{ECHA}$ registered products

${ }^{c}$ Active ingredient concentration

${ }^{d}$ Ready to Use

e Active ingredient concentration after dilution

${ }^{f}$ Defined EPA label contact time in minutes 
strains are EPA-defined strains required for biofilm disinfectant efficacy registration claims [20]. Disinfectants were tested at label contact times and concentrations. Phosphate buffered saline (PBS) was used as a control.

\section{Biofilm development on borosilicate glass coupons}

Biofilms were grown using EPA Standard Operation Procedure (SOP) MB-19 for biofilms using a Center for Disease Control (CDC) biofilm reactor (Biosurfaces Technologies, Inc., Bozeman, MT). Borosilicate glass coupons $(1.27 \pm 0.013 \mathrm{~cm}$; Biosurface Tech, Inc.) were used as carriers in the CDC biofilm reactor. The borosilicate glass coupons were placed in rods each containing three coupons. The biofilm reactor was positioned on a hotplate stirrer (Talbays, Thorofare, NJ) and filled with $500 \mathrm{~mL}$ of first phase growth media (Table 2). The media was inoculated with $1 \mathrm{~mL}$ of bacterial culture greater than or equal to $10^{7} \mathrm{CFU} / \mathrm{mL}$ (Table 2). This formed the batch phase. Each of the test microbes began to adhere to the coupons for $24 \mathrm{~h}$ under the conditions defined in Table 2 . The cells were subsequently grown in a continuous stirred tank reactor (CSTR) growth phase; 20 $\mathrm{L}$ of growth media (detailed in Table 2; TSB; Becton, Dickinson and Company, Sparks, MD) was pumped (Cole-parmer, Barrington, IL) through the reactor at a rate of $30 \pm 2$ min residence time for both $S$. aureus and $P$. aeruginosa.

\section{Disinfectant efficacy testing}

The efficacy of disinfectants against single strain biofilms was determined using EPA MLB SOP MB-20 [20]. Each rod contained three coupons and was rinsed by dipping in dilution water $\left(1.25 \mathrm{~mL} \mathrm{KH} \mathrm{KO}_{4}+5.0 \mathrm{~mL} \mathrm{MgCl} \cdot 6 \mathrm{H}_{2} \mathrm{O}\right)$. The target density for each coupon was 7.5-9.0 CFU/coupon for S. aureus and 8.0-9.5 CFU/coupon for P. aeruginosa per EPA MLB SOP MB-20. Coupons were placed in a $50 \mathrm{~mL}$ sterile conical tube (Corning Science, Mexico) for treatment and enumeration; coupons were individually evaluated. Five biological replicates were conducted for quaternary ammonium compounds due to known high variability [21]. Three biological replicates were conducted for sodium hypochlorite and hydrogen peroxide testing based on previous work conducted by our group [22]. Each biological replicate for all test products was composed of five technical replicates. Three control coupons were used for each test. Disinfectant product (four $\mathrm{mL}$ ) was added to each sterile conical tube containing a coupon. Coupons were dipped in dilution water prior to transferred into the tube to remove planktonic cells. Disinfectants were left in contact with the coupons for the label contact times at room temperature (Table 1). Four $\mathrm{mL}$ of PBS was added to control coupons. Disinfectant products were neutralized at the label-defined contact time with $36 \mathrm{~mL}$ neutralizing buffer solution $\left(1 \mathrm{~L} \mathrm{H}_{2} \mathrm{O}+\right.$ $5.2 \mathrm{~g}$ Difco neutralizing buffer; Becton, Dickinson and Company Sparks, MD). The treated coupons underwent a rotational series of vortexing (30 s) and sonication using an ultra-sonic water bath (Cole-Parmer Instrument Company, Chicago, IL) at $45 \mathrm{Khz}$ for $30 \mathrm{~s}$ three times to release the biofilms from the coupons and suspend the bacteria in solution [20].

The control samples were quantified by serial dilution and spread plating on Tryptic Soy Agar (TSA; BD Biosciences, San Jose, CA) for S. aureus and Reasoner's 2a Agar (R2a; Becton, Dickinson and Company Sparks, MD) for P. aeruginosa following EPA MLB SOP MB-20 [20]. Coupons treated with quaternary ammonium chloride disinfectants were serially diluted and plated due to high cell recovery; coupons treated with hydrogen peroxide and sodium hypochlorite-based disinfectants were not serially diluted. Ten $\mathrm{mL}$ aliquots from each diluted sample were vacuum-filtered onto a membrane filter $(0.2 \mu \mathrm{m}$ pore; Pall Corporation, Port Washington, NY). Membrane filters were plated onto TSA and R2a agar for $S$. aureus and $P$. aeruginosa, respectively, and incubated at $37^{\circ} \mathrm{C}$ for $48 \pm 4 \mathrm{~h}$ prior to estimation.

\section{Statistical analyses}

All statistical analyses were performed using SAS 9.4 (SAS Institute, Cary, NC). CFU $\log _{10}$ reductions were calculated and normalized relative to the number of CFUs on control coupons. Disinfectant products were grouped based on the main active ingredients: sodium hypochlorite (1 product), hydrogen peroxide (5 products), and quaternary ammonium compounds (2 products). The data were fitted in a generalized linear mixed model with Proc Glimmix procedure to determine if there were significant differences in $\log _{10}$ reductions among disinfectants both by active category and product $(n=56 ; \alpha=0.05)$. Least Squares Means with Tukey's adjustment were used to elucidate the trend of the identified significant differences.

Table 2 Growth conditions for S. aureus and P. aeruginosa biofilms

\begin{tabular}{|c|c|c|c|c|}
\hline Bacteria Strain & $\begin{array}{l}\text { Hotplate Stirrer } \\
\text { Settings }\end{array}$ & Test Culture preparation & $\begin{array}{l}\text { Batch phase growth } \\
\text { medium } 24 \mathrm{~h}\end{array}$ & $\begin{array}{l}\text { CSTR }{ }^{a} \text { growth } \\
\text { medium } 24 \mathrm{~h}\end{array}$ \\
\hline S. aureus ATCC-6538 & $60 \pm 5 \mathrm{rpm}$ at $36 \pm 1^{\circ} \mathrm{C}$ & $\begin{array}{l}\text { Frozen stock with } 10 \mathrm{ml} \mathrm{TSB}(30 \mathrm{~g} \mathrm{TSB} / \mathrm{L}) \\
\text { overnight at } 36 \pm 1{ }^{\circ} \mathrm{C}\end{array}$ & $3 \mathrm{~g} / \mathrm{L} \mathrm{TSB}$ & $1 \mathrm{~g} / \mathrm{L} \mathrm{TSB}$ \\
\hline P. aeruginosa ATCC-15442 & $125 \pm 5 \mathrm{rpm}$ at $21 \pm 2^{\circ} \mathrm{C}$ & $\begin{array}{l}\text { Frozen stock with } 10 \mathrm{~mL} \text { TSB }(300 \mathrm{mg} \text { TSB/L) } \\
\text { overnight at } 36 \pm 1{ }^{\circ} \mathrm{C}\end{array}$ & 300 mg/L TSB & 100 mg/L TSB \\
\hline
\end{tabular}

${ }^{\mathrm{a}}$ Continuously stirred tank reactor (CSTR) phase 


\section{Results}

Hydrogen peroxide- and sodium hypochlorite-based disinfectant products had similar bactericidal effects against both $S$. aureus and $P$. aeruginosa biofilms Regardless of bacterial strain, hydrogen peroxide and sodium hypochlorite disinfectants achieved a greater overall bactericidal efficacy than quaternary ammonium disinfectants, both by active ingredient category $(P<$ $0.0001)$ (Fig. 1$)$ and by individual product $(P<0.0001)$ (Fig. 2). Overall, S. aureus biofilms had a greater overall $\log$ reduction than $P$. aeruginosa biofilms after disinfection regardless of active ingredient category $(P<0.0001$; Fig. 1$)$ or the specific product applied ( $P=0.0002$; Fig. 2 ). A comparison of disinfectants by active ingredient category showed a significantly higher log reduction of $S$. aureus biofilms (4.37 log reduction) than $P$. aeruginosa biofilms (0.82 log reduction) by quaternary ammonium products $(P<0.0001$; Fig. 1$)$. Coupons disinfected with quaternary ammonium chloride products had on average $4.75 \pm 1.69$ S. aureus CFU/coupon (4.37 log reduction) and $8.02 \pm$ $0.60 P$. aeruginosa CFU/coupon (0.82 log reduction) post-treatment. There were no significant differences in bactericidal efficacy against $S$. aureus and $P$. aeruginosa biofilms after disinfection by hydrogen peroxide or sodium hypochlorite products. S. aureus and $P$. aeruginosa biofilms had an average log density of $0.33 \pm 0.06 \mathrm{CFU} /$ coupon (8.73 log reduction) and $0.30 \mathrm{CFU} /$ coupon (8.51 $\log$ reduction) after disinfection with hydrogen peroxide disinfectants, respectively (Fig. 1) per EPA MLB SOP MB-20, 0.30 CFU/coupon is the reported detection limit when no cells are recovered thus there is no calculable standard deviation. S. aureus and P. aeruginosa coupons disinfected with the sodium hypochlorite product had mean $\log$ densities of $0.30 \mathrm{CFU} /$ coupon (8.73 log reduction) and $0.33 \pm 0.08 \mathrm{CFU} /$ coupon (8.75 log reduction), respectively (Fig. 1).

When evaluating each disinfectant individually, both quaternary ammonium products exhibited significant differences in bactericidal efficacy against $S$. aureus and $P$. aeruginosa biofilms (Fig. 2). Specifically, S. aureus biofilms were significantly more reduced than the $P$. aeruginosa biofilms when treated with Q1 $(P<0.0001)$ and Q2 $(P=0.0001)$ (Fig. 2). No other significant differences were observed between $S$. aureus and $P$. aeruginosa biofilms disinfected by hydrogen peroxide or sodium hypochlorite products.

\section{Hydrogen peroxide and sodium hypochlorite disinfectants had significantly higher bactericidal efficacy against $S$. aureus biofilms than quaternary ammonium products}

There were significant differences in bactericidal efficacy among tested disinfectants against $S$. aureus both by active ingredient category $(P<0.0001$; Fig. 1$)$ and by individual product $(P<0.0001$; Fig. 2). Products with hydrogen peroxide and sodium hypochlorite as active ingredients achieved significantly higher $S$. aureus log reduction than quaternary ammonium-based products $(P<0.0001$; (Fig. 1). Specifically, sodium hypochlorite disinfectant $\mathrm{SH} 1$ and all hydrogen peroxide disinfectants (HP1, HP2, HP3, HP4, and HP5) individually by product were more effective against $S$. aureus biofilms than either of the two tested quaternary ammonium products $(P<0.0001$; Fig. 2$)$. There was no significant difference in bactericidal efficacy against $S$. aureus biofilms treated with Q1 compared to Q2 $(P>0.05$; Fig. 2$)$. There were no significant differences in disinfection performance among the aforementioned hydrogen peroxide and sodium hypochlorite products collectively $(P>0.05$; Fig. 2$)$.

\section{Hydrogen peroxide and sodium hypochlorite} disinfectants were more bactericidal against $P$. aeruginosa biofilms compared to quaternary ammonium compounds Bactericidal efficacy was significantly different among disinfectants applied to $P$. aeruginosa biofilms both by active ingredient category $(P<0.0001 ;$ Fig. 1$)$ and by

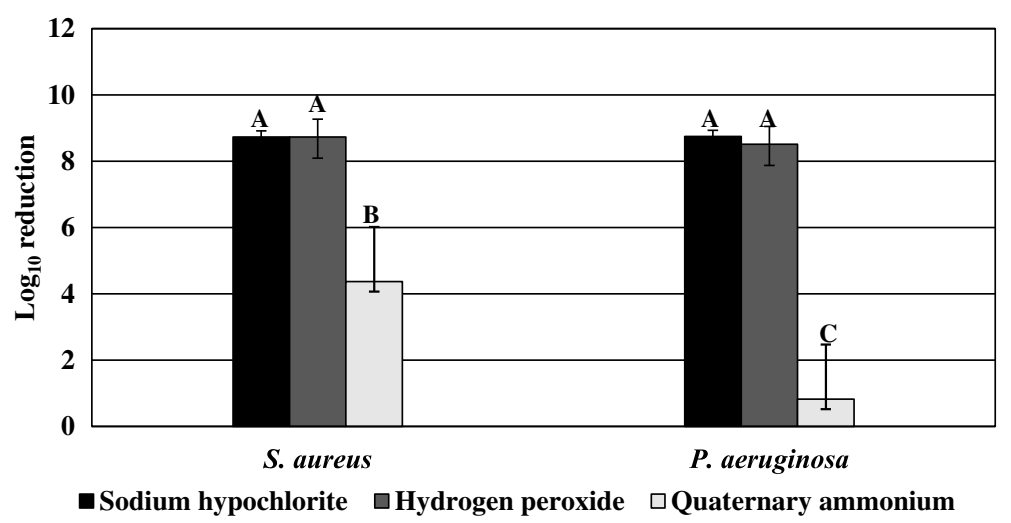

Fig. 1 Comparison of active ingredient class by strain 


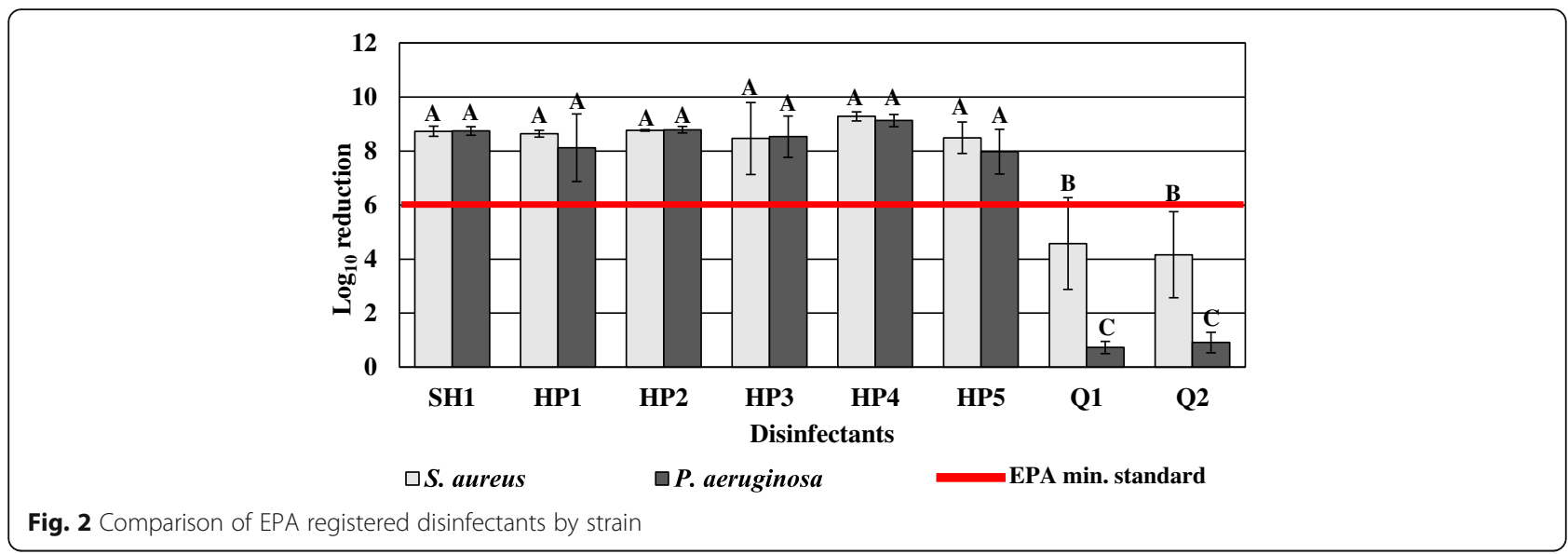

specific product $(P<0.0001$; Fig. 2$)$. Hydrogen peroxide and sodium hypochlorite-based disinfectants were more effective against $P$. aeruginosa biofilms than quaternary ammonium products $(P<0.0001$; Fig. 1$)$. Specifically, sodium hypochlorite disinfectant (SH1) and all hydrogen peroxide disinfectants (HP1, HP2, HP3, HP4, and HP5) by product individually achieved significantly higher bactericidal efficacy against $P$. aeruginosa than either of the quaternary ammonium chloride products $\mathrm{Q} 1$ and Q2 $(P<0.0001$; Fig. 2$)$. There were no significant differences among hydrogen peroxide products or between sodium hypochlorite disinfectant and hydrogen peroxide products $(P>0.05)$. There was no statistically significant difference in efficacy between the two quaternary ammonium products $(P>0.05)$.

\section{Discussion}

In this study, we tested eight registered disinfectants under label use conditions against $S$. aureus and P. aeruginosa biofilms using EPA methods MB-19 and MB-20. We found statistically significant quantitative differences among disinfectant active ingredients and products against $S$. aureus and $P$. aeruginosa. Specifically, we found (i) statistically significant differences in disinfectant efficacy among disinfectants, (ii) similar performance of hydrogen peroxide and sodium hypochlorite-based products against $S$. aureus and $P$. aeruginosa biofilms, and iii) significantly higher bactericidal efficacy of quaternary ammonium-based products against $S$. aureus than $P$. aeruginosa. Bacterial biofilms are common on a wide range of surfaces made of different materials and have been reported to be present in drains, metal pipes [10], sanitizing bottles, trolleys and clipboards [23] thus are potential sources of HAIs.

\section{Disinfectant efficacy varies by active ingredient}

We found significant differences among quaternary ammonium compound disinfectants compared to hydrogen peroxide and sodium hypochlorite disinfectants. The quaternary ammonium compounds did not achieve the current EPA regulation minimum stating that the disinfectant must decrease the bacterial load by $10^{6} \mathrm{CFU}$ [24]. The findings in this study underscoring low quaternary ammonium compound efficacy against laboratorygrown biofilms. This raises concerns for healthcare facilities as quaternary ammonium disinfectants are reported to be among the most commonly used disinfectants in healthcare facilities [25, 26]. Quaternary ammonium compounds are cationic in nature $[27,28]$ and their interaction with a negatively charged biofilm matrix could inhibit their bactericidal efficacy [29]. Tseng et al. found that the efficacy of tobramycin, a positively charged antibiotic, was decreased as it was sequestered at the surface of the negatively charged biofilm matrix thus did not penetrate the matrix to contact underlying viable $P$. aeruginosa cells [29]. In addition, the bactericidal efficacy of quartenary ammonium compounds may fluctuate because they have been shown to be biogradeble under aerobic condictions [30].

Hydrogen peroxide and sodium hypochlorite disinfectants were effective against $P$. aeruginosa and $S$. aureus biofilms at the EPA required reduction levels. Hydrogen peroxide and sodium hypochlorite disinfectants have been reported to destroy both the biofilm matrix and the bacteria cells within, making them better anti-biofilm agents [31, 32]. Specifically, sodium hypochlorite disinfectant products irreversibly kill bacterial cells in biofilms by denaturing proteins in the biofilm matrix and inhibiting major enzymatic functions in bacterial cells. Although sodium hypochlorite disinfectants at concentrations as low as $0.0219 \%$ are effective against the formation of S. aureus biofilms [33], the use of sub-lethal concentrations of some sodium containing disinfectants could actually promote the formation of biofilms on environmental surfaces [34]. In a study conducted by West et al. [22], hydrogen peroxide products and sodium hypochlorite products were more effective against both $S$. aureus and $P$. aeruginosa planktonic cells compared 
5. Vickery K, Deva A, Jacombs A, Allan J, Valente P, Gosbell IB. Presence of biofilm containing viable multiresistant organisms despite terminal cleaning on clinical surfaces in an intensive care unit. J Hosp Infect. 2012;80(1):52-5.

6. Rutala WA, Weber DJ. Disinfection, sterilization, and control of hospital waste. In Mandell, Douglas, and Bennett's principles and practice of infectious diseases. Vol. 2. Elsevier Inc. 2014. p. 3294-3309.e1; https://doi. org/10.1016/B978-1-4557-4801-3.00301-5.

7. Quinn MM, Henneberger PK, National Institute for Occupational Safety and Health (NIOSH), National occupational research agenda (NORA) cleaning and disinfecting in healthcare working group, Braun B, Delclos GL, Fagan K, Huang V, Knaack JL, Kusek L, Lee SJ, Le Moual N, Maher KA, SH MC, Mitchell AH, Pechter E, Rosenman K, Sehulster L, Stephens AC, Wilburn S, Zock JP. Cleaning and disinfecting environmental surfaces in health care: toward an integrated framework for infection and occupational illness prevention. Am J Infect Control. 2015;43(5):424-34.

8. Smith K, Hunter IS. Efficacy of common hospital biocides with biofilms of multi-drug resistant clinical isolates. J Med Microbiol. 2008;57:966-73.

9. Dantes R, Mu Y, Belflower R, Aragon D, Dumyati G, Harrison LH, Lessa FC, Lynfield R, Nadle J, Petit S, Ray SM, Schaffner W, Townes J, Fridkin S. Emerging infections program-active bacterial Core surveillance MRSA surveillance investigators. National burden of invasive methicillin-resistant Staphylococcus aureus infections, United States, 2011. JAMA Intern Med. 2013;173:1970-8

10. Liu J, Luo Z, Liu K, Zhang Y, Peng H, Hu B, Ren H, Zhou X, Qiu S, He X, Ye P, Bastani H, Lou L. Flushing on the detachment of biofilms attached to the walls of metal pipes in water distribution systems. J Zhejiang Univ-Sci A. 2017;18:313-28.

11. Kramer A, Schwebke I, Kampf G. How long do nosocomial pathogens persists on inanimate surfaces? A systemic review. BMC Infect Dis. 2006;6:130.

12. Percival S, Cutting $K$, Thomas J, Williams D. An introduction to the world of microbiology and biofilmology. In: Percival S, Cutting K, editors. Microbiology of wounds. Boca Raton: CRC Press; 2010.

13. Abdallah M, Khelissa O, Ibrahim A, Benoliel C, Heliot L, Dhulster P, Chihib NE. Impact of growth temperature and surface type on the resistance of Pseudomonas aeruginosa and Staphylococcus aureus biofilms to disinfectants. Int J Food Microbiol. 2015;214:38-47.

14. Bridier A, Briandet $R$, Thomas V, Dubois-Brissonnet F. Resistance of bacterial biofilms to disinfectants: a review. Biofouling. 2011;27:1017-32.

15. Buckingham-Meyer K, Goeres DM, Hamilton MA. Comparative evaluation of biofilm disinfectant efficacy tests. J Microbiol Methods. 2007;70:236-44.

16. Davison WM, Pitts B, Stewart PS. Spatial and temporal patterns of biocide action against Staphylococcus epidermidis biofilms. Antimicrob Agents Chemother. 2010;54:2920-7.

17. Fagerlund A, Møretrø T, Heir E, Briandet R, Langsrud S. Cleaning and disinfection of biofilms composed of Listeria monocytogenes and background microbiota from meat processing surfaces. Appl Environ Microbiol. 2017. https://doi.org/10.1128/AEM.01046-17.

18. Donlan RM. Biofilms: microbial life on surfaces. Emerg Infect Dis. 2002:8:881-90.

19. Meyer B, Cookson B. Does microbial resistance or adaptation to biocides create a hazard in infection prevention and control? J Hosp Infect. 2010;76:200-5.

20. Environmental Protection Agency. Methods and guidance for testing the efficacy of antimicrobial products against biofilms on hard, non-porous surfaces. EPA. 2017. https://www.epa.gov/pesticide-analytical-methods/ methods-and-guidance-testing-efficacy-antimicrobial-productsagainst\#efficacy-data. Accessed 2 Nov 2018.

21. Hong Y, Teska PJ, Oliver HF. Effects of contact time and concentration on bactericidal efficacy of 3 disinfectants on hard nonporous surfaces. Am J Infect Control. 2017. https://doi.org/10.1016/j.ajic.2017.04.015.

22. West AM, Teska PJ, Oliver HF. There is no additional bactericidal efficacy of EPAregistered disinfectant towelettes post-surface drying or beyond label contact time. Am J Infect Control. 2018;7:122. https://doi.org/10.1016/j.ajic.2018.07.005

23. Ledwoch K, Dancer SJ, Otter JA, Kerr K, Roposte D, Rushton L, Weiser R, Mahenthiralingam E, Muir DD, Maillard JY. Beware biofilms! Dry biofilms containing bacterial pathogens on multiple healthcare surfaces; a multiple center study. J Hosp Infect. 2018;100:e47-56.

24. Environmental Protection Agency. Efficacy testing standards for product data call in responses. EPA; 2015. https://www.epa.gov/sites/production/files/2017 05/documents/reregistration_efficacy_standards.pdf. Accessed 1 Aug 2018.

25. McBain AJ, Ledder RG, Moore LE, Catrenich CE, Gilbert P. Effects of quaternary ammonium-based formulations on bacterial community dynamics and antimicrobial susceptibility. Appl Environ Microbiol. 2004; 70(6):3449-56.
26. Gerba CP. Quaternary ammonium biocides: efficacy in application. 2015 Appl Environ Microbiol. 2015;81(2):464-9.

27. Nasioudis A, Joyce WF, Van Velde JW, Heeren RMA, Van den Brink OF. Formation of low charge state ions of synthetic polymers using quaternary ammonium compounds. Anal Chem. 2010;82:5735-42.

28. Velpandian T, Jayabalan N, Arora B, Ravi AK, Kotnala A. Understanding the charge issues in mono and di-quaternary ammonium compounds for their determination by LC/ESI-MS/MS. Anal Lett. 2012;45(16):2367-76.

29. Tseng BS, Zhang W, Harrison JJ, Quach TP, Song JL, Penterman J, Singh PK, Chopp DL, Packman Al, Parsek MR. The extracellular matrix protects Pseudomonas aeruginosa biofilms by limiting the penetration of tobramycin. Environ Microbiol. 2013;15:2865-78.

30. Tezel U, Spyros GP. Quatenary ammonium disinfectants: microbial adaptation, degradation and ecology. Environ Biotech. 2015;33:296-304 https://doi.org/10.1016/j.copbio.2015.03.018

31. DeQueiroz GA, Day DF. Antimicrobial activity and effectiveness of a combination of sodium hypochlorite and hydrogen peroxide in killing and removing Pseudomonas aeruginosa biofilms from surfaces. J Appl Microbiol. 2007. https://doi.org/10.1111/j.1365-2672.2007.03299.x.

32. Tiwari S, Rajak S, Mondal DP, Biswas D. Sodium hypochlorite is more effective than $70 \%$ ethanol against biofilms of clinical isolates of Staphylococcus aureus. Am J Infect Control. 2018:46:e37-42.

33. Barnes TM, Greive KA. Use of bleach baths for the treatment of infected atopic eczema. Australas J Dermatol. 2013;54:251-8.

34. Cincarova L, Polansky O, Babak V, Kulich P, Kralik P. Changes in the expression of biofilm-associated surface proteins in Staphylococcus aureus food-environmental isolates subjected to sublethal concentrations of disinfectants. Biomed Res Int. 2016. https://doi.org/10.1155/2016/4034517.

35. Boyce MJ, Guercia KA, Sullivan L, Havill NL, Fekieta R, Kozakiewicz J, Goffman D. Prospective cluster controlled crossover trial to compare the impact of an improved hydrogen peroxide disinfectant and a quaternary ammoniumbased disinfectant on surface contamination and health care outcomes. Am J Infect Control. 2017;45:1006-10.

36. Omidbakhsh N. A new peroxide-based flexible endoscope-compatible high-level disinfectant. Am J Infect Control. 2006;34:571.

37. Rutala WA, Weber DJ. Disinfection of endoscopes: review of new chemical sterilants used for high-level disinfection. Infect Control Hosp Epidemiol. 1999;20:69.

38. Alfa MJ, Jackson M. A new hydrogen peroxide-based medical-device detergent with germicidal properties: comparison with enzymatic cleaners. Am J Infect Control. 2001;29:168.

39. Mitchell KF, Zarnowski R, Sanchez H, Edward JA, Reinicke EL, Nett JE, Mitchell AP, Andes DR. Community participation in biofilm matrix assembly and function. Proc Natl Acad Sci U S A. 2015;112:4092-7.

40. Al-Jailawi M, Ameen R, Al-Jeboori MR. Effect of disinfectants on antibiotics susceptibility of Pseudomonas aeruginosa. J Appl Biotechnol. 2013. https://doi.org/10.5296/jab.v1i1.4038.

41. Gilbert P, Das JR, Jones MV, Allison DG. Assessment of resistance towards biocides following the attachment of microorganisms to, and growth on, surfaces. J Appl Microbiol. 2001;91:248-54.

Ready to submit your research? Choose BMC and benefit from:

- fast, convenient online submission

- thorough peer review by experienced researchers in your field

- rapid publication on acceptance

- support for research data, including large and complex data types

- gold Open Access which fosters wider collaboration and increased citations

- maximum visibility for your research: over $100 \mathrm{M}$ website views per year

At $\mathrm{BMC}$, research is always in progress.

Learn more biomedcentral.com/submission 